\title{
皮膚通電抵抗と良導絡その 2
}

第五章 皮廜通電、通過電流量の比較 に関する研究

\section{第一項 楮 佥} いる。或る二点（とれを $\mathrm{A}$ 点、B点と仮定し）のうち その一点 $\mathrm{A}$ 点は $30 \mu \mathrm{A}$ 流れ、他の一点 $\mathrm{B}$ 然は50 $\mu \mathrm{A}$ 流れ ているとする。そして又或る一点Cに刺数を与えた場 合、 $\mathrm{A}$ 点の $30 \mu \mathrm{A} か 50 \mu \mathrm{A}$ となり、B点の $50 \mu \mathrm{A}$ か $70 \mu \mathrm{A}$ になる。ての場合、 $\mathrm{C}$ 点の刺激は、 $\mathrm{A}$ 点及び $\mathrm{B}$ 点に同 じ程度に作用したすのであろうか、或は $\mu \mathrm{A}$ 数の大き いすのは小さいすのより多く反応するとすればA点の 方強く作用したと考えられる。との様な比較の問題 は将来必要になる。しかしての問題は人体に於ける反 応である為に確実なる比較は難しい。それでこの一つ の方法として、次の様なととを行った。

第一実呀、代表测定点12ケ所で一時間おきに10日間 にわたって測定した。この場合代表列定点で測定した 電流量によって $0 \sim 9 \mu \mathrm{A} 、 10 \sim 19 \mu \mathrm{A} 、 20 \sim 29 \mu \mathrm{A}$ 、 $30 \sim 39 \mu \mathrm{A} 、 40 \sim 49 \mu \mathrm{A} 、 50 \sim 59 \mu \mathrm{A} 、 60 \sim 69 \mu \mathrm{A}$ という 様に分けて、それが一時間の後に、何 $\mu \mathrm{A}$ 変動したか をしらへた。てれはこれぞれの $\mu \mathrm{A}$ 量単位が自然的に どのぐらい変野するかを知る為に行ったものである。

次は、代表良㭩点20ケ所で測定したすので、それを
皮庙は䉓圧の変化によって皮革を通る電流量が異る ので所定の测定器で通過電流量を测定するとととして

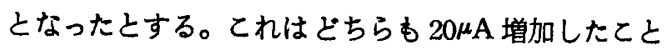

中 谷 義 雄

\author{
3 山○ 守○ 38 才男性 背部痛 \\ 4 玉○カ○エ 56才女性 局とり \\ 5 川○リ○子 40 才女性 頭痛 \\ 6 中○百○子 28 才女性 倦怠感 \\ 7 岡O 一 56 才男性 肋間痛 \\ 8 富OモOI 63才女性 子宮癌 \\ 9 入○ 道○ 23才女性 心脿神経症 \\ 10 上O 松O 43才女性 頭痛 \\ $11 川$ 年O 17才男性 胃漬韵 \\ 12 山○ 好○ 39才女性 不眠症 \\ 13 森O 保 32 才男性 消化不良症 \\ 14 中○ 寅○ 56才男性 上半身痛 \\ 15中○千○子 31才女性 頭痛 \\ (2) 実験装置
}

第一実験、第二実験ともに良導点電流量測定装置

（3）実験方法

第一実験左側の代表測定点を一時間、間隔で測

定、一時間に於ける変化を求めた。

第二実験 $\mathrm{H}_{2} \mathrm{H}_{5}$ 良導絡の代表良尊点をのぞく他の 全部（左右）の20代表良導点で測定した施炎直前 と施炎刺激 15 分 30分後に於ける变化を求めた。

（4）実験成績

\section{第三項 考 按}

第一実験の成績をみると $0 \sim 9 \mu \mathrm{A}$ は一時闃の後に は相当大きい変化を示しており、20 $\mathrm{A}$ 代、 $40 \mu \mathrm{A}$ 代が 一番小さい変化を示している。全般的にみると $10^{\mu} \mathrm{A}$ 前の様に $0 \sim 9 \mu \mathrm{A} 20 \sim 29 \mu \mathrm{A}$ という様に分 けて、各所に施负刺激を与えて、どの単位 がどの程度通䉓変化したかをしらへたた。 れによって、业量が大きいもの程よく反 応するか、又それがどの程度強く反応する かということを知ることが出来るわけであ る。

\section{第二項 实 䀦}

(1) 実験資料

第一実験自然的変化の測定 中○千O子 29才女性 健康体 中○ 広O 17才女性 健康体 第二実験负刺激に上る変化の测定 1 上O美O代 21 才女性 肺浸湖 2 辻○夕○ 70 才女性 腰痛

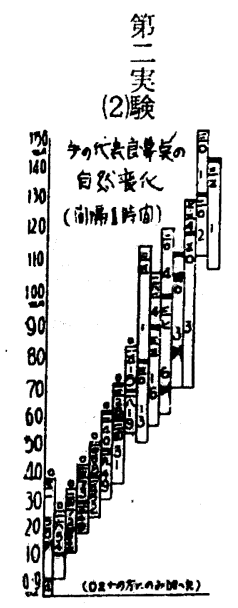

第18図
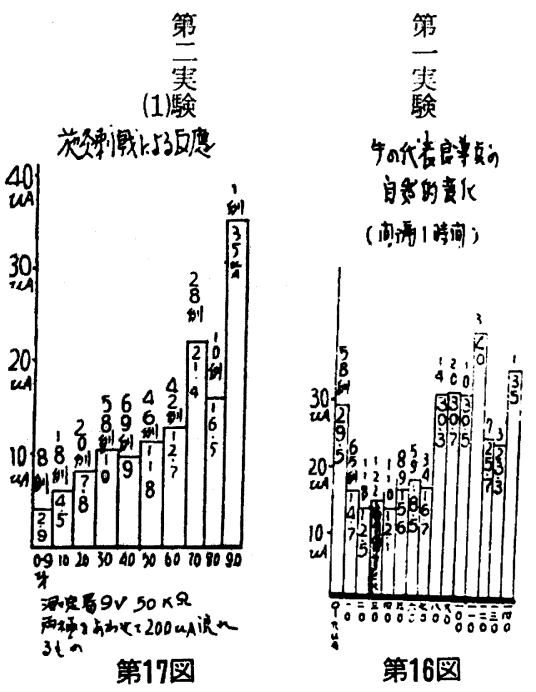
代より $70 \mu \mathrm{A}$ 代までは同程度の変化を示している。

次に第二実験(1)の成績をみると第一実験之は少し異 り $\mu \mathrm{A}$ 量の大きいあの程その施炎刺激に対する反対が 大きい様に思われる。 $40 \mu \mathrm{A}$ 代が稍変化が少いが、代 表測定点の合計平均が約 $40 \mu \mathrm{A}$ であるので、 $40 \mu \mathrm{A}$ は生 理的健康值と考えられる。随ってその反応が少いので はないかと考えている。それに、第一実験之異る点 は、第一実験では $0 \sim 9 \mu \mathrm{A}$ では大きく変化している が、第二実験の $0 \sim 9 \mu \mathrm{A}$ はその反応が小さいととで ある。乙の様な相違は、第一実験では健康体に於ける 測定であり、第二実験では病人であることが関係した と考えられる。疾患によって或る良導絡が鮮明に現わ れたり、或は反対に不良導絡となるこうした通電抵抗 の変化を起さしめた疾患の為に病的に変化せしめられ た第二実験 では $0 \sim 9 \mu \mathrm{A}$ 代では反応が少ないと考え ている。

第二実験(2)は第一実験(1)の $\mu \mathrm{A}$ 量の増加したあのと 減少したものに分けて書いたものである。 $\mu \mathrm{A}$ 量の少 いむのでは $\mu \mathrm{A}$ 量が増加する例数も多く、反応する $\mu \mathrm{A}$ 量む多い。10 $\mathrm{A}$ 代では59例中55 例上昇している、そ の上昇反応の平均 $\mu \mathrm{A}$ 量は $31 \mu \mathrm{A}$ である。 $40 \mu \mathrm{A}$ 量以上 では減少例数す反応 $\mu \mathrm{A}$ 量す下降する方が多い。自然 的な変化亡、众刺激による变化を比較すると、尒刺激 を与えたから、大きく反応したわけですない。とする と尒刺激は影響がないと謂うことになるが、刺激によ って選択的に通電抵抗を変化させるととが出来る。

\section{第四項 結 論}

人体皮酢に対する無刺敫状態及び施众刺激による各 単位に於ける変化反応 $\mu \mathrm{A}$ 量をみると、大体に於て、 $20 \mu \mathrm{A} \sim 60 \mu \mathrm{A}$ ぐらいの間に於ては、その反応 $\mu \mathrm{A}$ 量を 10\%〜 30\%の 誤差を考える時は比較するととが出来 る。刺激による反応 $\mu \mathrm{A}$ 量の比較には前掲第二実験(1) の曲線を参考にすれば相当正確な比洨をすることが出 来る。

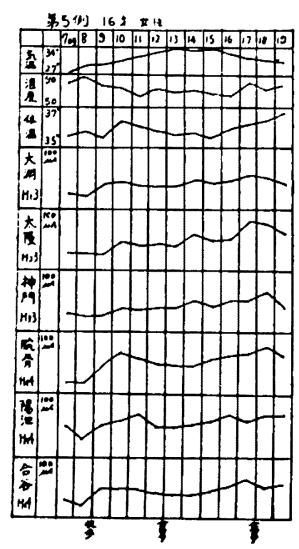

第23表

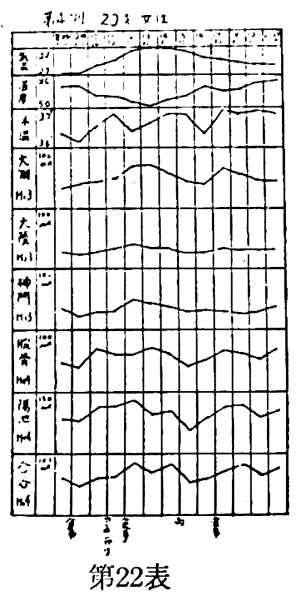

第22表

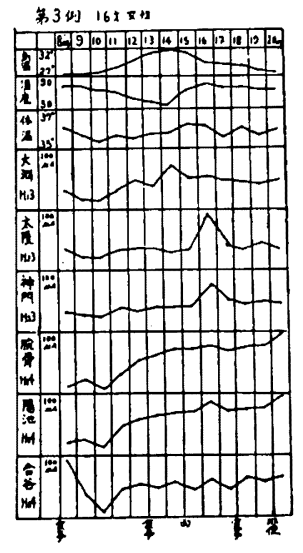

第21表
第 6 章 日常生活が良導絡に及ぼす影 響

\section{第1 項 緒 言}

代表測定点に関する研究(第 4 章)で、各良導絡の興 奋性の変化を代表測定点で知ることが出来る。それで その代表測定点の測定を行い、日常生活に於ける生活 条件や生活状態（気温、湿度、体温、食事、㛹、排 尿、運動等）によって良導絡の興奮性が如何に変化す るかを知るために測定は 1 時間間隔で行うこととし た。

\section{第 2 項 実 䀦}

(1) 実験資料

中○千○子 29才女性 健康体

中○ 広○ 17才女性 健康体

(2) 実験装置

良導点電流量測定装置

（3）実験方法

左側手の代表良導点 $\mathrm{H}_{1}{ }^{3} 、 \mathrm{H}_{2}{ }^{3} 、 \mathrm{H}_{3}{ }^{3} 、 \mathrm{H}_{4}$ 、 $\mathrm{H}_{5} 4 、 \mathrm{H}_{6} 4$ で 1 時間間隔で測定、その都度、気温

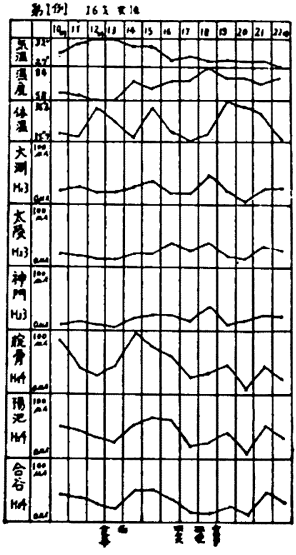

第 19 表 湿度、体温を測定し、1 日に13回測定した。その 閭、食事、排便、排尿、 アイロンがけ、徒歩、運 動、哄笑、雨等の条件を 記入した。ての測定 2 人 で5 日間の実験が終って 後足の代表湘定点、 $\mathrm{F}_{\mathbf{1}^{3}}$ $\mathrm{F}_{2}{ }^{3}, \mathrm{~F}_{3}{ }^{3}, \mathrm{~F}_{4}{ }^{4}, \mathrm{~F}_{5}{ }^{5}$ $\mathrm{F}_{6} 5$ で前同様測定した。

（4）実験成績

手の代表測定点測定成績 は次表 記載の如くであ る。

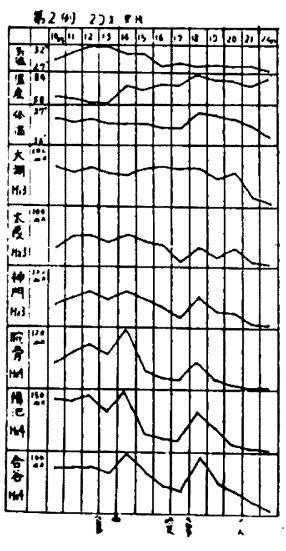

第20表 

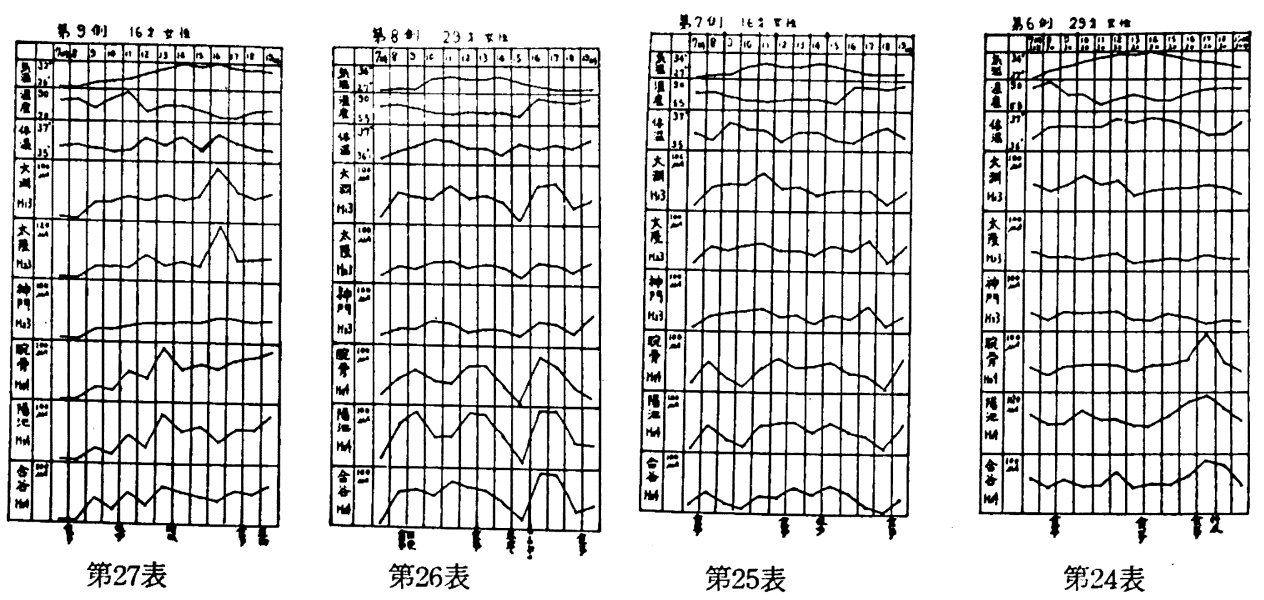

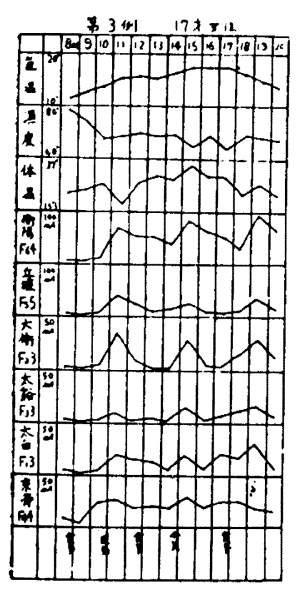

第31表

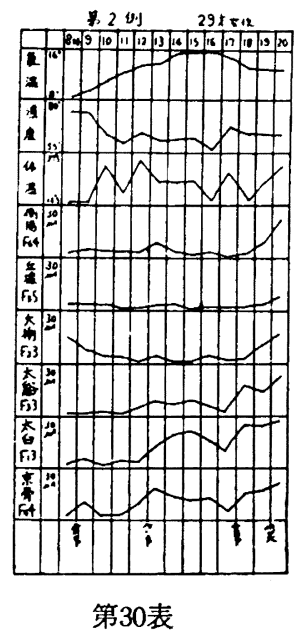

第30表

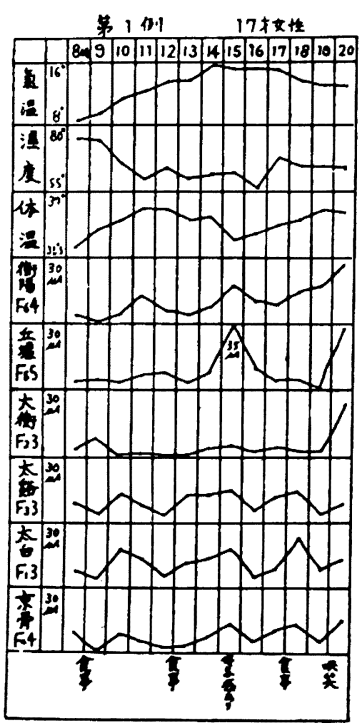

第29表

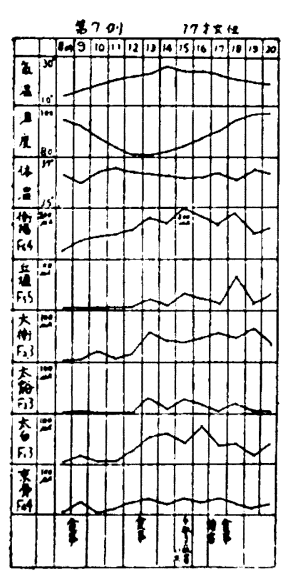

第35表

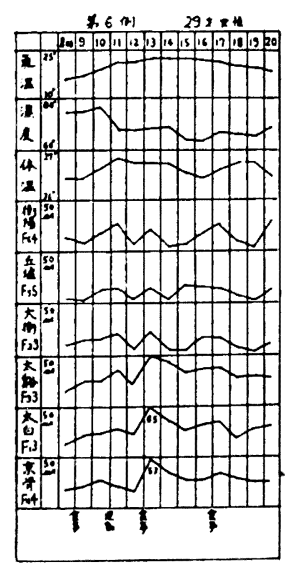

第34表

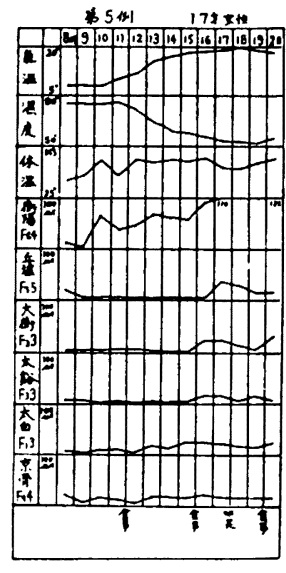

䇷33表
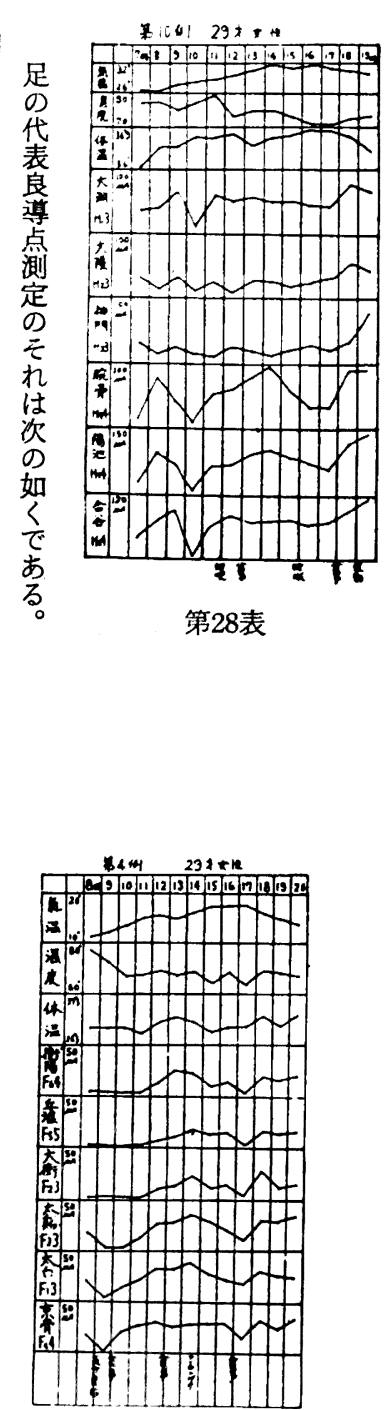

第32表 


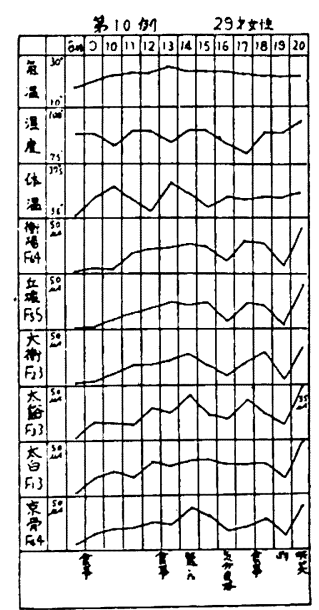

第38表

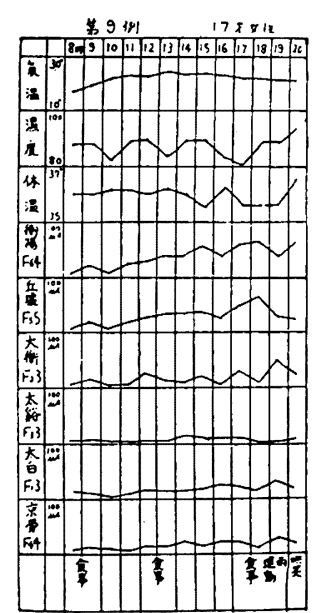

第37表

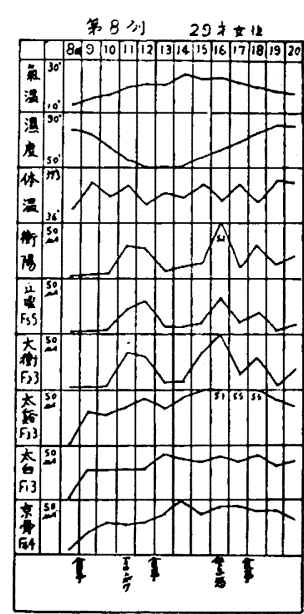

第36表

\section{第 3 項 考 按}

通電抵抗は気温、湿度、体温によって左右されるて とは生理学上より考えても当然なととである。しか し、この実験成績よりみる時は他の因子がそれ以上強 く作用するものか、一定の法則のむとに影響されてい る様に思われない。即ちこのととは影響があっても、 影響が少いと謂うととになる。各代表測定点に於ける 電流量の変化を右表曲線でみると手では $\mathrm{H}_{1}{ }^{3} 、 \mathrm{H}_{2}{ }^{3}$ 、 $\mathrm{H}_{3}{ }^{3}$ は相似的変化を示し、 $\mathrm{H}_{4}{ }^{4} 、 \mathrm{H}_{5}{ }^{4} 、 \mathrm{H}_{6}{ }^{4}$ は又相似 変的化を示している。足では手程鮮明ではないが、 $\mathrm{F}_{1}{ }^{3} 、 \mathrm{~F}_{3}{ }^{3} 、 \mathrm{~F}_{4}{ }^{4}$ は相似的変化を示し、 $\mathrm{F}_{2}{ }^{3} 、 \mathrm{~F}_{5}{ }^{5}$ 、 $\mathrm{F}_{6} \mathbf{4}^{4}$ は相似的変化を示している。乙の曲線形の変化か ら、食事や排便による電流量の変化等についてしらべ てみた即ち食事後の測定電流量から、食事前の測定電 流量を引いた差、食事に関係ありと解される。排便で は、排便後の電流量から排便前の電流量を引いた残り の電流量が排便に関係ありと思われる。食事では手の 代表良導点の測定で25例あり、足の代表良導点で30例 ある。随っで、手では食後の電流量25例を加算し、25 で割ると平均值が出る。次に食前の電流量25例を加算
し、25で割ると平均值が出る。その食後の平均值より 食前の平均值を引いた差が $\mathrm{H}^{3}$ (肺) では6. $2 \mu \mathrm{A}$ であ り、 $\mathrm{H}_{2}{ }^{3}$ では $5.5^{\mu} \mathrm{A} 、 \mathrm{H}_{3}{ }^{3}$ (心では $5.5 \mu \mathrm{A} 、 \mathrm{H}_{4}^{4}$ (小

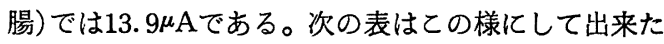
あのである。

この表をみると食事によっては $\mathrm{H}_{4}^{4}$ (小腸)、 $\mathrm{H}_{5}{ }^{4}$ (淋巴管)、 $\mathrm{F}_{\mathbf{8}} \mathbf{4}$ (胃)が一番反応している。又排便では 食事によって電流量の増加したものが、却って減少し ているととは興味がある。排尿では $\mathrm{F}_{\mathbf{4}}^{4}$ (膀胱)の反応 が一番少い。乙のととは排尿によって全般的に通電抵 抗が減少(交感神経)緊張したと考え度い。排尿によっ て膀腅関係の興秵性が減少したと考えると、端的に理 解がつくと思われる。

\section{第 4 項 結 語}

皮屏通電抵抗は日常生活に於て刻々として変化して いる。殊に食事、排便、排尿、哄笑の如き日常生活状 態か著明にその変動に影響している。

\begin{tabular}{|c|c|c|c|c|c|c|c|c|c|c|c|c|c|c|}
\hline & & & \multirow{2}{*}{\multicolumn{6}{|c|}{$\frac{f}{f}$}} & \multicolumn{6}{|c|}{5} \\
\hline & & & $(m)$ & & & & & & $(1)$ & 4 & $\operatorname{lin} x$ & & & (ant \\
\hline 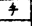 & 2 & $26 \ln$ & H, 3 & $\mathrm{H}_{2} 3$ & $\mathrm{H}_{3} 3$ & H.4 & $H_{64}$ & H.4 & $F_{4} 4$ & F.5 & $F .4$ & $F, 3$ & $F, 3$ & $F, 3$ \\
\hline $25 n$ & $30 m$ & 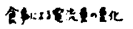 & 6.2 & 5.5 & 5.5 & |13.9. & 14.4 & 8 & 8.7 & 4.9 & 44 & 43 & 6.7 & 3.6 \\
\hline 40 & - & 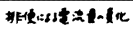 & 2.5 & 9.5 & 12.5 & -3.8 & -8.8 & -5 & 6.6 & 3.1 & 1.0 & -2 & -1.5 & 0.1 \\
\hline & 248 & 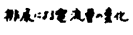 & & & & & & & 3.4 & 4.5 & 0.2 & 0.8 & 1.1 & 3.3. \\
\hline $100 \mathrm{~m}$ & 59 & 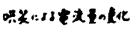 & 14.2 & 9.3 & 7.8 & -0.3 & -4 & -42 & 25 & 11 & 9.2 & 8.6 & 4 & 52 \\
\hline & $3 m$ & 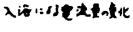 & & & & & & & 27 & 11 & -07 & 6 & & 28 \\
\hline $2 m$ & & 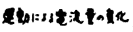 & -5 & $\mid-10$ & 55 & 15 & 50 & 30 & & & & & & \\
\hline 241 & & 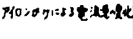 & 31.5 & 15 & 18 & 54.5 & 67 & 50.5 & & & & & & \\
\hline 4n & & $251632 x+40$ & 14 & 4 & 9 & 21 & 31 & 32 & & & & & & \\
\hline
\end{tabular}

第39表 


\section{第七章 同一良恧絡上の各良導点刺激が その各々の良糞点に及ぼす影響}

\section{第 1 項 諸 言}

同一良導絡上の良導点 1 つつつ施众刺激を与えて その都度、それらの良導点汇於ける通電抵抗值が如何 に反応するかを知る為に各良導絡上に10１2の良導点 を選びえに刺激を与えた結果を測定してみた。これに よって同一良導絡上に於ける各良導点の相関関係を知 るととが出来る。

\section{第 2 項 実 䀦}

(1) 実跧資料

(A) $\mathrm{H}_{1} \mathrm{H}_{5} \mathrm{H}_{6} \mathrm{~F}_{2} \mathrm{~F}_{6}$ 良導絡の实験は 中○義O 32才 男性 健冰体

(B) $\mathrm{F}_{4}$ 良導絡の実験は

川O八○ョ 45才 女性 坐骨神経狱

(2) 実験装置

実験用皮消通電抵抗测定装罚

時間的つれをなくする為と、電極の条件を一定にす る為之の目的で夷験用皮简通電抵抗測定装置を用い た。

(3) 実験成絈

左表は $\mathrm{H}_{1}$ 良欺絡の $\mathrm{H}_{1} 1 \mathrm{H}_{1} 2 \mathrm{H}_{1} 3 \mathrm{H}_{1} 4 \mathrm{H}_{1} 5 \mathrm{H}_{1} 6 \mathrm{H}_{1} 7$ $\mathrm{H}_{1} 8 \mathrm{H}_{1} 9 \mathrm{H}_{1} 10 \mathrm{H}_{1} 11 \mathrm{H}_{1} 12$ 良照点に米粒 大施尒刺激を 各一壮つつ与えたものでその刺激直前と直後に於て $\mathrm{H}_{1} 1 \mathrm{H}_{1} 2 \mathrm{H}_{1} 3 \mathrm{H}_{1} 4 \mathrm{H}_{1} 5 \mathrm{H}_{1} 6 \mathrm{H}_{1} 7 \mathrm{H}_{1} 8 \mathrm{H}_{1} 9 \mathrm{H}_{1} 10 \mathrm{H}_{1} 11$ $\mathrm{H}_{1} 12$ の各良導点で皮仙近電抵抗を测定した。横に並

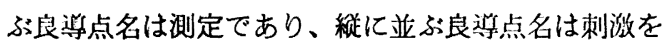
示している。测定部位及ご刺激部位は同一の良導点に なっているが、刺湤部位は測定部位のすぐ横（ $\mathrm{H}_{2}$ 良 導絡侧）である。 $\mathrm{H}_{1} 1$ を刺激する前の通電 $\mu \mathrm{A}$ 量は
$\mathrm{H}_{1} 1$ では20 $\mu_{\mathrm{A}} 、 \mathrm{H}_{1} 2$ では $9 \mu \mathrm{A} \mathrm{H} \mathrm{H}_{1} 3$ は $11 \mu \mathrm{A} \mathrm{H} \mathrm{H}_{1} 4$ は $13 \mu \mathrm{A} \mathrm{H}_{1} 5$ は $15{ }^{\mu} \mathrm{A}$ …であり、 $\mathrm{H}_{1} 1$ に米粒大施众を一 壮行って、その直後同一部位で通電抵抗を測すると、 $\mathrm{H}_{1} 1$ では $20 \mu \mathrm{A} か ゙ 30 \mu \mathrm{A} に な っ て い る 。 ~ H_{1} 2$ は $9 \mu \mathrm{A}$ $5{ }^{\mu} \mathrm{A}$ に 13 は $5 \mu \mathrm{A} 、 \mathrm{H}_{1} 4$ は $10 \mu \mathrm{A} 、 \mathrm{H}_{1} 5$ は $13 \mu \mathrm{A}$ そ……...なってる。上段は刺湤直前の通電 $\mu \mathrm{A}$ 量で あり、下段は刺激直後の通電 $\mu \mathrm{A}$ 量である。その差を 次の表に示した。との表によってH 11 に米粒大一壮の 刺激を与えた処刺激を与えた部位の通電 ${ }^{\mu} \mathrm{A}$ 量は $10 \mu \mathrm{A}$ 增加し、 $\mathrm{H}_{1} 2$ は $4 \mu \mathrm{A}$ 減少、 $\mathrm{H}_{1} 3$ 6 $6 \mu \mathrm{A}$ 減少、 $\mathrm{H}_{1} 4$ б $3 \mu \mathrm{A}$ 減少と云う結果を得た。この表より考察すると $\mathrm{H}_{11}$ と $\mathrm{H}_{1} 10$ が最む関係深いのではなかろうか、それ

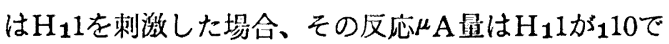
最高で、次はH110の-8である。 $\mathrm{H}_{1} 1$ は刺激部位である から、それをのぞくと、 $\mathrm{H}_{1} 1$ と $\mathrm{H}_{1} 10$ とが最む閉係深 いと解される。勿諭この一例をむって、 $\mathrm{H}_{1} 1$ と $\mathrm{H}_{1} 10$ とが最も関係が深いと断言するのではなく、とうした 関係を知る為の方法としてての様なととが必要であ り、之を統計するてとによって同一良導絡上の各良導 点間の相関関係を知ることが出来るわけである。

\section{第3 項 考 按}

以上の実験は $\mathrm{H}_{1} 、 \mathrm{H}_{5} 、 \mathrm{H}_{6} 、 \mathrm{~F}_{2} 、 \mathrm{~F}_{6}$ 良導絡各一 例の变化であるので、との各一例つつの変化をもって どの良導点はどの良導点と関係が哚い之謂う様な事は 䚴えない。しかし、ての変化が一定の法則性をむって いると調うことは、このデーターにより第四章の代表 测定点に関する研究の第一実験上り第五実検の良等絡 の緊張度の変化と代表測定点の変化が現われているの で、一定の法則性のもとに反応したものと考え得よ う。但し例類が少いので前記の如く之と以て普通罗当 律とする処迄考えることは何うかと思われる。

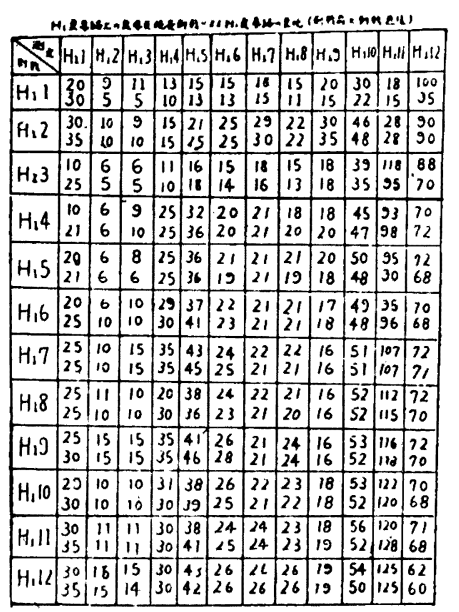

第 40 表

\begin{tabular}{|c|c|c|c|c|c|c|c|c|c|c|c|c|}
\hline$m^{2}$ & & & & & H,S & $H, 6$ & $\begin{array}{r}4.7 \\
\end{array}$ & $H_{1}, 8$ & $H, 1$ & & Holl & 4,12 \\
\hline$H_{11} 1$ & 10 & -4 & -6 & -3 & -2 & -2 & -3 & -4 & -5 & -8 & & -5 \\
\hline$H_{1} 2$ & 5 & 0 & 1 & 0 & 4 & 0 & 1 & 0 & 5 & 2 & 0 & 0 \\
\hline$H_{13}$ & 15 & -1 & -1 & -1 & 2 & -1 & -2 & -2 & 0 & -4 & $|-23|$ & -18 \\
\hline$H_{14}$ & 11 & 0 & 1 & 0 & 4 & 0 & 0 & 2 & 2 & 2 & 5 & 2 \\
\hline$H_{1} S$ & 1 & 0 & -2 & 0 & 0 & -2 & 0 & -2 & -2 & -2 & $-5-$ & -4 \\
\hline$H_{1} 6$ & 5 & 4 & 0 & 1 & 4 & 1 & 0 & 0 & 1 & -1 & 1 & -2 \\
\hline$H_{17}$ & 0 & 0 & 0 & 0 & 2 & 1 & -1 & -1 & 0 & 0 & 0 & $\cdot 1$ \\
\hline $\mathrm{H}, 8$ & 0 & -1 & 0 & 19 & -2 & -1 & -1 & -1 & 0 & 0 & 3 & -2 \\
\hline $\mathrm{H}_{1} \mathrm{O}$ & 5 & 0 & 0 & 0 & 5 & 2 & 0 & 0 & 0 & -1 & 2 & -2 \\
\hline$H, 10$ & 1 & 0 & 0 & 1 & 1 & -1 & -1 & 1 & 0 & -1 & -2 & -2 \\
\hline$H_{1} 11$ & 5 & 0 & 0 & 0 & 3 & 1 & 0 & 0 & 1 & -4 & 8. & -3 \\
\hline 4,12 & 5 & 0 & -1 & 0 & -1 & 0 & 0 & 0 & 0 & -4 & 0 & -2 \\
\hline
\end{tabular}

第 4 項 結 語

尒刺湤に刘する良等絡の反応は刺 激部位が一番強く反応すると謂う梯 なととはない。寧ろ刺激点から遠方 の良尊点に幽い反応を生じている梯 な所がある。左右の圆係で反対側へ 刺激勃果が相当強く及んでいる。 

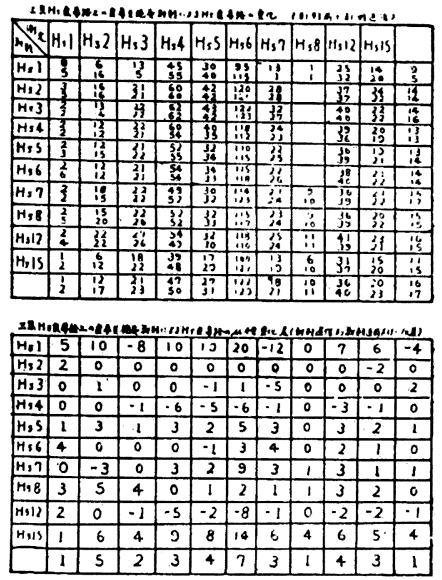

第 42 表

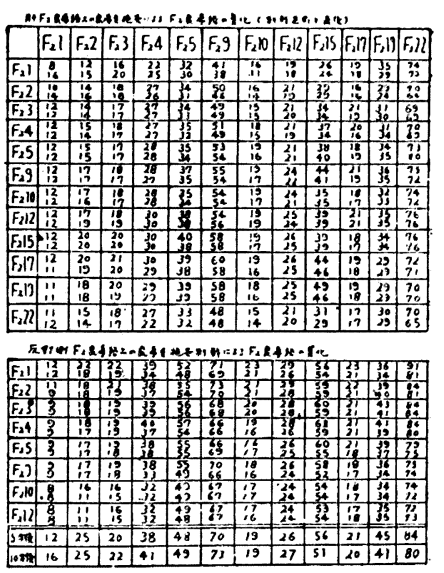

第 45 表

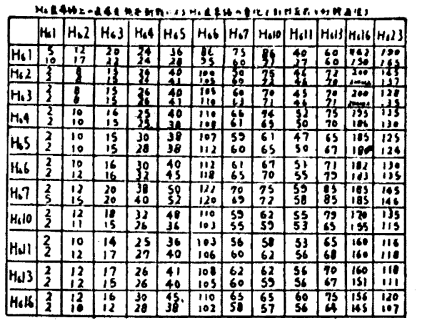

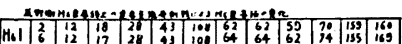

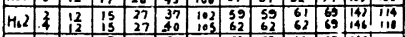

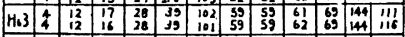

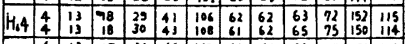

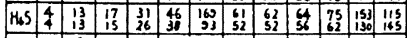

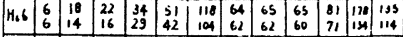

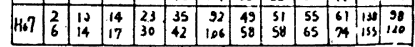
第 43 表

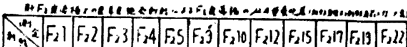
\begin{tabular}{llllllllllllllll}
\hline$F_{2}$ & 8 & 3 & 4 & 3 & -2 & -3 & -5 & -1 & -2 & -1 & -6 & -4 \\
\hline
\end{tabular}

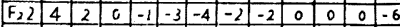

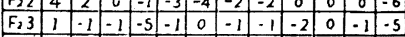

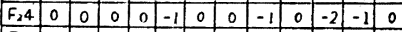
\begin{tabular}{l|l|l|l|lllllllllll}
$F_{2} 5$ & 0 & -1 & -1 & 0 & -3 & -2 & -3 & -2 & -3 & -4 & 3 & -1 \\
\hline$F_{2}$ & 0 & 0 & 0 & 0 & -1 & 1 & -3 & 0 & 2 & 1 & 1 & 7 \\
\hline
\end{tabular} \begin{tabular}{c|ccccccccccccc}
$F_{2} O$ & 0 & 0 & 0 & 0 & -1 & 1 & -3 & 0 & 2 & 1 & 1 & 7 \\
\hline$F_{2}$ & 0 & 0 & -1 & -1 & -2 & -1 & -2 & -2 & -3 & -2 & -1 & -3 \\
\hline
\end{tabular} \begin{tabular}{llllllllllllll}
$F_{2} 10$ & 0 & 0 & -1 & -1 & -2 & -1 & -2 & -2 & -3 & -2 & -1 & -3 \\
\hline$F_{1}$ & 0 & -1 & -1 & 0 & -1 & 0 & -2 & -3 & 0 & -1 & -1 & -2 \\
\hline
\end{tabular}

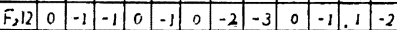

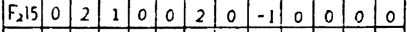
\begin{tabular}{llllllllllllllll}
\hline$F_{2} 7$ & 0 & 0 & 0 & 0 & -2 & 0 & -2 & -1 & 0 & -1 & 0 & 0 \\
\hline
\end{tabular}

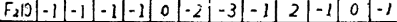

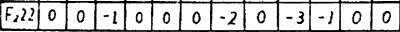

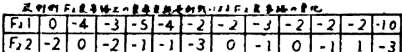

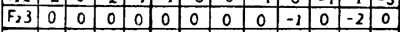

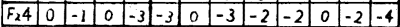
\begin{tabular}{lllllllllllllll}
\hline$F_{2} 5$ & 0 & 0 & -1 & 0 & 0 & 3 & 1 & -1 & -5 & -3 & -2 & -4 \\
\hline
\end{tabular} \begin{tabular}{|l|l|l|l|l|l|c|c|c|c|c|c|c|}
$F_{2} 5$ & 0 & 0 & -1 & 0 & -1 & 3 & 1 & -1 & -5 & -3 & -2 & -4 \\
\hline$F_{2} 3$ & 0 & 0 & -1 & -5 & -6 & -4 & -2 & -2 & -6 & -1 & -2 & -1 \\
\hline$F_{2}$ & 0 & -5 & -1 & 0 & 0 & 0 & 0 & 0 & 0 & -1 & 0 & -2 \\
\hline
\end{tabular}

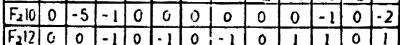
第 46 表
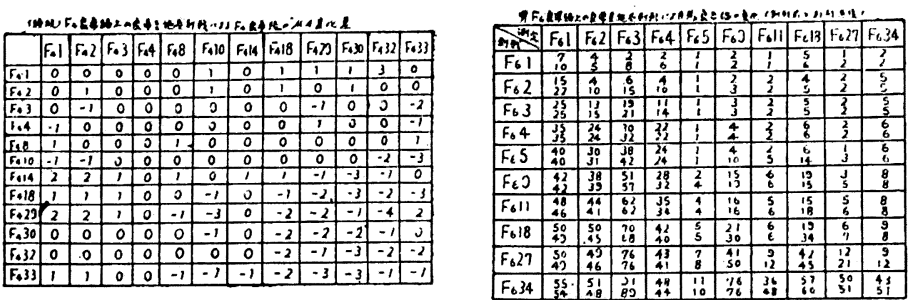

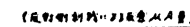

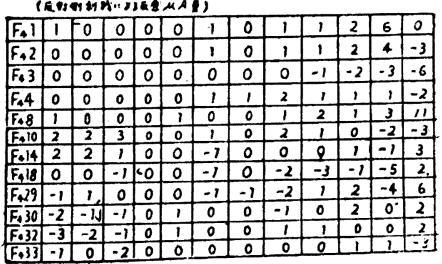

第 48 表

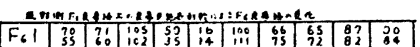

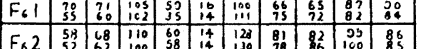

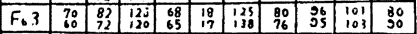

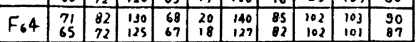

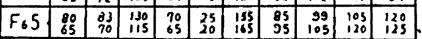

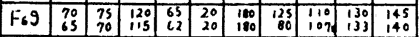

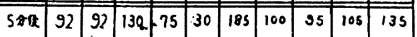

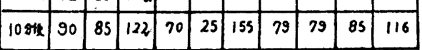

第 49 表

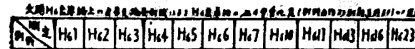

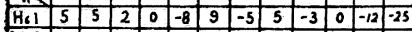

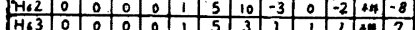

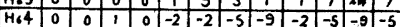
\begin{tabular}{lllllllll|l|l|l|l}
\hline 45 & 0 & 0 & 0 & -2 & 0 & 5 & 1 & 4 & 3 & 2 & -5 & -1 \\
\hline
\end{tabular} \begin{tabular}{lllllllllllllllll}
$H .6$ & 0 & 2 & 0 & 2 & 5 & 6 & 4 & 3 & 4 & 8 & 1 & 5 \\
\hline
\end{tabular} \begin{tabular}{llllllllllllllll}
\hline$H_{6} 7$ & 3 & 3 & 0 & 2 & 2 & -2 & -1 & -3 & -1 & 0 & 0 & 1 \\
\hline
\end{tabular}

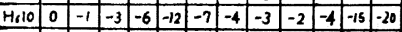
\begin{tabular}{lllllllll|l|l|l|l|l|l}
$H_{6} 11$ & 0 & 2 & 3 & 2 & 4 & 3 & 4 & 4 & 3 & 3 & 0 & 2 \\
\hline$H_{6} 1$ & 0 & 0 & -2 & 0 & -1 & -3 & -2 & -3 & 0 & -3 & -9 & -7 \\
\hline
\end{tabular} \begin{tabular}{llllllllllllllll}
$H$ & 0 & 13 & 0 & 0 & -2 & 0 & -1 & -3 & -2 & -3 & 0 & -3 & -9 & -7 \\
\hline$H(1)$ & 0 & -2 & -4 & -2 & -7 & -8 & -7 & -8 & -4 & -1 & -1 & -13 \\
\hline
\end{tabular}

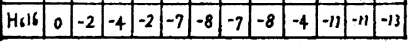

\begin{tabular}{|l|l|l|l|l|l|l|l|l|l|l|l|l|}
\hline$H_{6}$ & 4 & 0 & -1 & 0 & 0 & 0 & 2 & 2 & 3 & 4 & -4 & 9 \\
\hline
\end{tabular} \begin{tabular}{|l|llllllllllllll|}
\hline $\mathrm{H} 62$ & 2 & 0 & 0 & 0 & 3 & 3 & 3 & 3 & 1 & 0 & 4 & 4 \\
\hline $\mathrm{H} 3$ & 0 & 0 & -1 & 0 & 0 & -7 & 0 & 0 & & 2 & 0 & \\
\hline
\end{tabular}

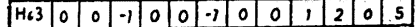
\begin{tabular}{|l|llllllllllllll|}
\hline$H_{6} 4$ & 0 & 0 & 0 & 1 & 2 & 2 & -1 & 0 & 2 & 3 & -2 & -1 \\
\hline$H_{6}$ & 0 & 0 & -2 & -5 & -16 & -1 & & \\
\hline
\end{tabular}

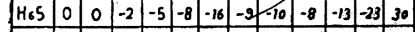

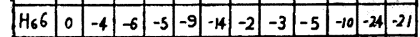
\begin{tabular}{|l|l|l|l|l|l|l|l|l|l|l|l|l|}
\hline $\mathrm{H}_{67}$ & 4 & 4 & 3 & 7 & 7 & 14 & 9 & 7 & 10 & 13 & 17 & 22 \\
\hline
\end{tabular}

第 44 表

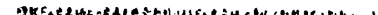

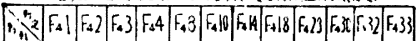

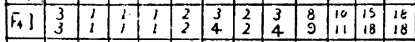

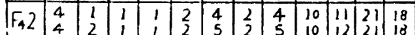

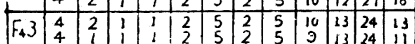

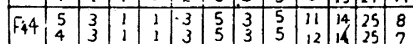
\begin{tabular}{|l|l|l|lllllllllll}
\hline$F_{4} 8$ & 6 & 4 & 1 & 1 & 3 & 6 & 4 & 7 & 12 & 15 & 25 & 5 \\
\hline
\end{tabular} \begin{tabular}{|llllllllllllll}
\hline$F_{4} 10$ & 9 & 5 & 1 & 1 & 4 & 7 & 4 & 9 & 14 & 18 & 28 & 6 \\
\hline
\end{tabular} \begin{tabular}{|l|lllllllllllll}
\hline$F_{4} 14$ & 12 & 7 & 4 & 1 & 4 & 0 & 4 & 13 & 12 & 22 & 22 & 11 \\
\hline
\end{tabular} \begin{tabular}{lllllllllllllll}
16 & 10 & 7 & 1 & 4 & 8 & 4 & 14 & 10 & 20 & 27 & 14 \\
\hline
\end{tabular}

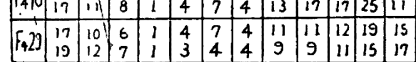

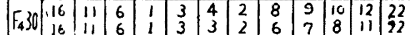

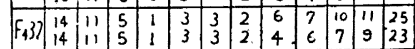

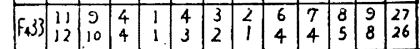
第 47 .表

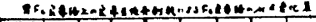

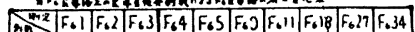

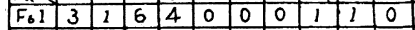

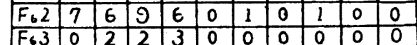

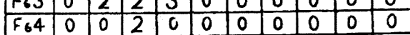

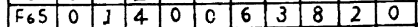

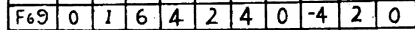

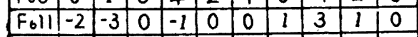

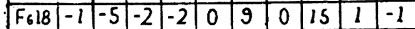
\begin{tabular}{|l|l|l|l|l|l|l|l|l|l|l|}
\hline$F_{6}, 27$ & -1 & -3 & 0 & -2 & 1 & 9 & 3 & 3 & 9 & 3 \\
\hline$r_{00}+1$ & 1 & 3 & 2 & 4 & 2 & 0 & 12 & 3 & 1 & 8 \\
\hline
\end{tabular}

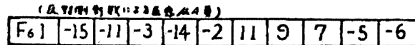

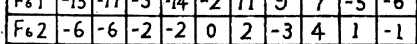
\begin{tabular}{|l|l|l|l|l|l|l|l|l|l|l|}
\hline$F_{6} 3$ & -10 & -10 & -5 & -3 & -1 & 13 & -4 & -1 & 2 & 10 \\
\hline
\end{tabular} \begin{tabular}{llllllllllllll}
\hline$F_{6} 4$ & -6 & -10 & -5 & -1 & -2 & -13 & -3 & 0 & -2 & -3 \\
\hline$F_{6}$ & -15 & -13 & -15 & -5 & -5 & 10 & 10 & 6 & 15 & 5 \\
\hline
\end{tabular} \begin{tabular}{|l|l|l|l|l|l|l|l|l|l|l|}
\hline$F_{6} 5$ & -15 & -13 & -15 & -5 & -5 & 10 & 10 & 6 & 15 & 5 \\
\hline
\end{tabular} \begin{tabular}{|l|l|l|l|l|l|l|l|l|l|l|}
\hline$F_{6}$ & -5 & -5 & -5 & -3 & 0 & 0 & -45 & -3 & 3 & -5 \\
\hline
\end{tabular} \begin{tabular}{|l|l|l|l|l|l|l|l|l|l|l|}
\hline 5810 & 22 & 17 & 10 & 10 & 10 & 5 & -25 & -15 & -25 & -10 \\
\hline
\end{tabular}

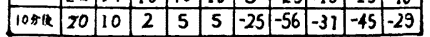
第 50 表 


\section{第八章 同一良導絡上の諸良辛点に対す} る刺激が他の良導絡に及ぼす影缽

\section{第1 項 諸 音}

同一良導絡上の 重要と思われる良導点に 刺激を加 え、他の良導絡の代表測定点でその刺激効果を測定 し、どの良導点はどの良導絡に特に影梪するかを知ろ うとした。古典経絡説によると各経絡に井栄俞経合と 謂う位置を定めている（第四章代表測定点に関する研 究で 井栄邻経合の位置を示した）。そして陰経（肺 経、心経肝経、留経、脾経、心包経、) では井は木性 の性質をもち、栄は火性の性質をむち、钞は、土性、 経は 金性合は 水性の性犋をあつとされている。陽経 （小腸経、大腸経、膀脱経、胆経、用経、三焦経）で は井は金性策は水性、俞は木性、経は火性、合は土性 の性質をむっているとされている。

木性とは肝胆、火性とは心、小腸、土性とは脾胃、 金性之は肺、大腸、水性は督、膀胱灾意味する。乙れ は陰経の、例えば肺経の井穴を剌激すると木性である から、肝経、胆経を刺激したと同じ意味になる。肺経 の栄穴を刺激すると火性であるから心経、小腸経を刺 激したと同じ意味になる。との様なととが良導絡にも 存在するや否やを知る為に井栄网経合に相当する良導 点に刺激を与えて各代表測定点で測定した。

\section{第 2 項实䀫}

(1) 実験資料

中○義○ 32才 男性 健康体

(2) 実験装置

実験用測定装䇴

（3）実験方法

$\mathrm{H}_{1}$ （肺）良導絡上の井栄前経合にあたる良導点、 $\mathrm{H}_{1} 1$

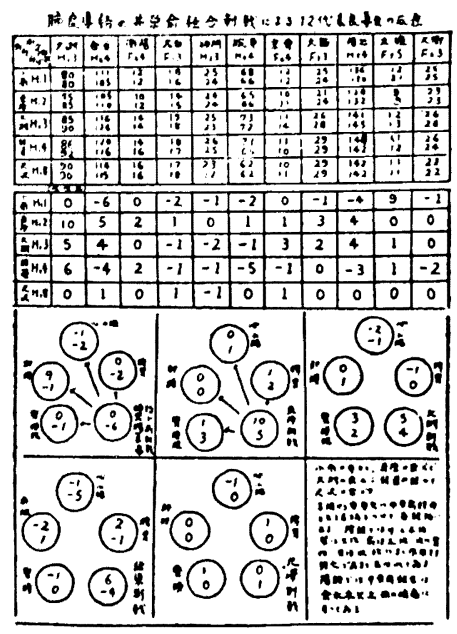

第 51 表
$\mathrm{H}_{1}$ 2、 $\mathrm{H}_{1} 3 、 \mathrm{H}_{1} 4 、 \mathrm{H}_{1} 8 \mathrm{~V}$ 施尒（米粒大一壮）刺激を 与えて各良導絡上の代表良学点でその反応を測定た。

(4) 実験成緽

第3 項 考 按

$\mathrm{H}_{1} 1$ 学刺激した場合は $\mathrm{F}_{5} 5$ (胆) に $9 \mu_{\mathrm{A}} \mathrm{A}$ 变化を与 えている。これは古典の栍に一致している。 $\mathrm{H}_{1} 2$ を 刺激した場合は $\mathrm{H}_{1} 3$ (刺) が10 $\mu \mathrm{A}$ で最高、古典の火 性に一致していない。 $\mathrm{H}_{1}$ 3を刺激した場合 $\mathrm{H}_{1} 3$ (肺) が5 $\mu \mathrm{A}$ 変化している。之は古典の土性に一致してい ない。 $\mathrm{H}_{14}$ を刺激した場合 $\mathrm{H}_{13}$ (肺) が $6 \mu \mathrm{A}$ 变化し ている。古典の土性に一致しているが、 $\mathrm{H}_{1} 2 、 \mathrm{H}_{1} 3$ 、 $\mathrm{H}_{1} 4$ を刺激した場合、皆 $\mathrm{H}_{1} 3$ が強く反応しているの

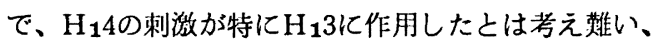

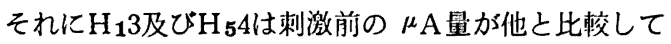
大きいので反応が大きく現われると考えられるからそ の関係は真实性にとほしい。 $\mathrm{H}_{1} 8$ を刺游した場合、 $\mathrm{H}_{64}$ (大腸) $\mathrm{F}_{13}$ (脾)、 $\mathrm{H}_{3} 3$ （心）、 $\mathrm{F}_{44}$ （膀胱） が各 $1 \mu \mathrm{A}$ づつ変化しているので、古典の水性が特に 関係深いとは誚えない。H13の反応が特に多いのでそ れを除外して考察しても、古典とは一致しない方が多 い。

\section{第 4 項 䊅 語}

同一良導絡上の古典井栄俞経合にあたる良導点を刺 激した場合、この一例に於ては古典に調う、井は木、 栄は火、俞は土、経は金、合は水性と調った性質は良 導絡に於ては認られなかった。

\section{第九章 五伝導方向に関する研究}

\section{第1 項 腥 吾}

五伝等方向とは古典五行説の相生、相勊線の方向を 謂う、五行説は宇宙の自然原理である易学から、人体は 小宇出であると調うので人体にとり入れられたあのと 調われている。获に大胆な仮定がその前提に探り入れ られている訳である。それまでは三陰三照説が有力で あった。科学の無い時代のことであるので、法則は哲理 として系統つけられたと謂って上かろう。太極が分れ て陰酇となり、陰陽が分れて三陰三陽となり、之れが 手足に配当されて手の三陰三䍀、足の三陰三䍀となり 手足をあわせて十二経となると述へている。五行説は 其の後に系統だてられたもので、天地の森羅万象は、 木火土金水から成るとし、木は火を生み、火は土を生 み、土は金劣生み、金は水を生む。乙の関係定相生関係 とよび、五要䒺閌に於ける親和的関係を示していると したあのである。

木は土を哯し、土は水を起し、水は火を兛し、火は 
金究起し、金は木を赾す。この阅係を五行相赾とよび、 紊間に於ける反撥的闺係を示すとしている。装問の著 者は五行に天地のあらゆる自然相を当てはめていると 同時に、人体の生活現像莛屯悉く是に当は好て観察し ている。即ち木に肝、胆、火に心，小㛣、土に脾、周 金に䏒、大腸、水に腎、膀胱を配当している。缄腑に 或は経絡に以上の様な五行的関係が存在するか否かに ついて鍼炎医学の古典派之現代科学派之の間に論争さ れた。しかし、是は水卦論に終った。それは、どちら にあ肯定或は否定する科学的根拋が無かったからだと 云ってよかろう。良導絡に以上の㥞な相生、相勊、五 行の㥞な性質が存在するか否かを窥ふ為に各良導絡に 刺激を与え、それ定代表测定点で測定して、どの良導 絡を刺激した場合、どの良奨絡が最も強く反応する か、或はどの良導絡の興褯性が高まっている時に、ど の良導絡の興鈿性が低下しているか等について実験し て右の如き相関が窅へるか否かの考察を加えてみた。

\section{第 2 項 実 験}

(1) 実験資料

第一实験 中○義○ 32 才 男性健㽷体

第二実験 中○義○ 32才 男性健康体

第三実験 中○義○ 32 才 男性健康体

刺激結果の正確を期する為汇著者自身に就いて検証 を試みた。

（2）実験装置

第一実験 実験用測定装置

第二実験 指圧

第三実験 良導点電流量测定装品

(3) 実験方法

第一実験、実験用測定装置の銀板電極を左代表測定 点12力処に䊼創高で固定し、 $\mathrm{H}_{1} 8 、 \mathrm{H}_{2} 8 、 \mathrm{H}_{3} 7 、 \mathrm{H}_{4} 8$ 、
$\mathrm{H}_{5} 11 、 \mathrm{H}_{6} 11, \mathrm{~F}_{19}, \mathrm{~F}_{28}, \mathrm{~F}_{3} 11, \mathrm{~F}_{4} 12 、 \mathrm{~F}_{5} 11 、$ $\mathrm{F}_{6}$ 9 $\mathrm{k}$ 米粒大各一壮施尒した。

第二笑験、例一では F 511 究指圧し、痛くなるまで 行なう。次に $\mathrm{F}_{4} 6$ 学指圧し、 $\mathrm{H}_{1} 10 、 \mathrm{~F}_{6} 9 、 \mathrm{H}_{4} 7$ の順 に指圧する。例二では $\mathrm{F}{ }_{5} 11 、 \mathrm{~F}_{4} 6 、 \mathrm{H}_{4} 7 、 \mathrm{H}_{6} 10$ 、 $\mathrm{H}_{6}$ 9、 $\mathrm{H}_{4} 7 、 \mathrm{~F}_{5}$ 11の順で指王する。

第三実験、 $\mathrm{F}_{5} 11 、 \mathrm{~F}_{4} 6 、 \mathrm{H}_{6} 10 、 \mathrm{~F}_{6} 9 、 \mathrm{H}_{4} 7$ で通電 抵抗を測定し $\mathrm{F}_{5} 11 、 \mathrm{~F}_{4} 6 、 \mathrm{H}_{6} 10 、 \mathrm{~F}_{6} 9 、 \mathrm{H}_{4} 7$ のすぐ 内側を指圧して（痛くなるまで）その都度測定した。

（4）実験成績

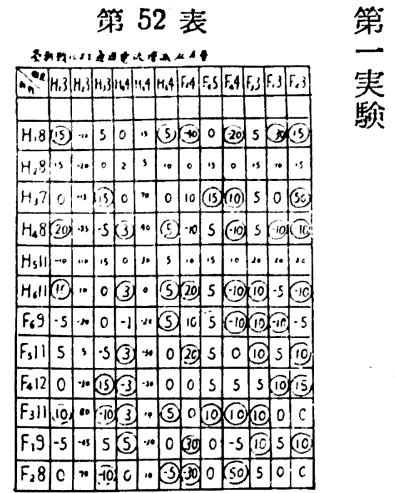

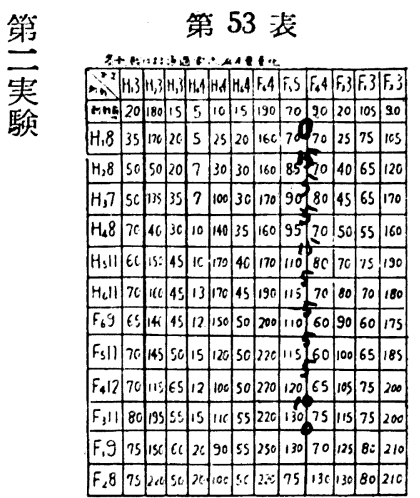
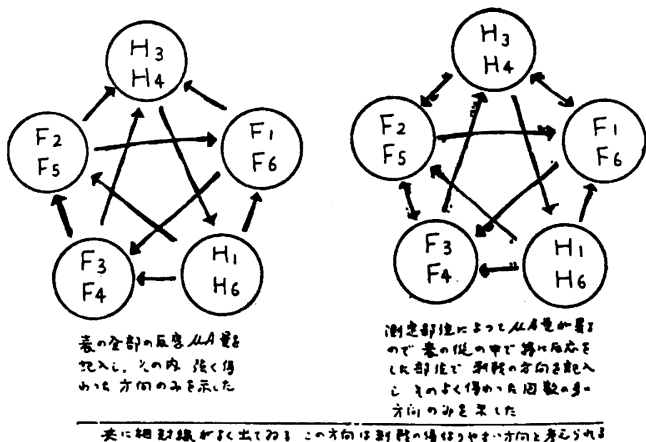

第 27 図 


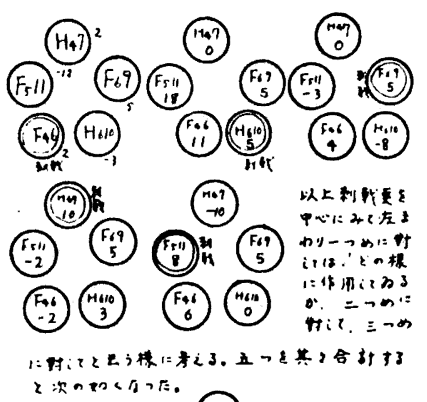

(32)

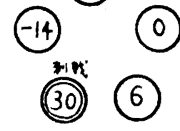

第 29 図

\section{第3 項 考 按}

第一実験、尒刺湤による通過電流量 $(\mu \mathrm{A})$ の変化 によって增減 $\mu \mathrm{A}$ 量を求めた処、各代表良導点の $\mu \mathrm{A}$ 量が $5 \mu \mathrm{A}$ から $190 \mu \mathrm{A} の$ 间に相当大なる開きがあるの で、代表良導点の $\mu \mathrm{A}$ 冝の変化、縱の中で特に変化し たものを求めて

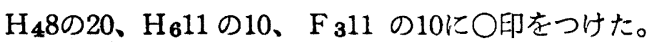
以下同じ。てうして出来上った表について考察するに $\mathrm{H}_{1} 8$ を刺激すると $\mathrm{H}_{1} 3 、 \mathrm{H}_{6} 4 、 \mathrm{~F}_{6} 4 、 \mathrm{~F}_{4} 4 、 \mathrm{~F}_{1} 3 、 \mathrm{~F}$ $2^{3}$ 亿強く作用したと解される。 $\mathrm{H}_{3} 7$ 定刺激すると、 $\mathrm{H}$ 33、F 55、F 44、F 23 亿強く作用したと解される。乙 の㥞に強く作用する方向に法則性がないか否かについ て考察した。

古典の五行説に是をあてはめて解釈を試 みると、 $\mathrm{F}^{2}$ と $\mathrm{F}_{5}$ は一つのグループであり。 $\mathrm{F}_{3}$ と $\mathrm{F}_{4} 、 \mathrm{H}_{1}$ と $\mathrm{H}_{6} 、 \mathrm{~F}_{1}$ と $\mathrm{F}_{6} 、 \mathrm{H}_{3}$ と $\mathrm{H}_{4}$ とが一つのグループになっ

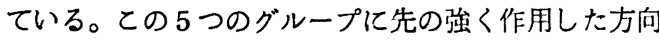
をあてはめ、その $\mu \mathrm{A}$ の多い即ち強く作用した方向の み示すと古典の相生、相起線とれ相似的形態が得ら ろ。

それに強く作用した $\mu \mathrm{A}$ 昌でなく、よく作用した回 数の多い方向を示すと、やはり古典相生、相赾線之相 似的結果が得られる。(60)

第二実験 $\mathrm{F}_{5} 11$ （胆良導絡上の良導点を指䶭し、疼 痛を起させ、他の良等点に指圧を加えて、F 511 の指 压痛が怪減するや否やをしらべた。その結果、F4良 等絡上以外の良筫点では $\mathrm{F}_{5} 11$ の指圧宿は柽隇しなか った。 $\mathrm{F}_{4} 6$ を指圧すると $\mathrm{F}_{5} 11$ の指圧痛は怪隇し $\mathrm{F}_{4} 6$ 指圧痛が強くなった。

次は $\mathrm{F}_{4} 6$ 6指圧痽を柽減せしめる良照点を求めた。 $\mathrm{H}_{6}$ 10を指圧すると $\mathrm{F}_{4}$ 6の指圧演は轻減した。古典に 謂う、相生線の逆の方向に、その指圧痽が転移寸るの
感がある。相赾線及びその逆では、指圧痛は転移しな かった。これは相生線と、相起線に相違があるととと 解される。(61)

第三実験、第二実験の相生線逆方向、指圧痛転移の 状態と通電抵抗の関係を知る為に行ったもので、F 5 $11 、 \mathrm{~F}_{4} 6 、 \mathrm{H}_{6} 10 、 \mathrm{~F}_{6} 99 . \mathrm{H}_{4} 7$ 、で测定し、測定部位の すぐ内侧を痛みを起すまで指圧した。それぞれを指圧 して各測定部位の電流量の変化を測定した。そして、 指圧部の通電抵抗と他の 4 つに対する通電抵抗の変化 を 5 つ合計してみると、刺激（指圧）部位は $30 \mu \mathrm{A}$ 増

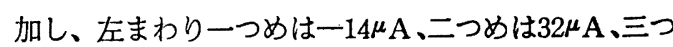
めは $\mathrm{O} \mu \mathrm{A}$ 、四つめは $6 \mu \mathrm{A}$ となっている。指圧部位 はこの例では指圧直後に於ては交感神経の興奮性が高 まり、左まわり一つめに於ては交感神経の與奎性が抑 制されていると解される。てれは指圧によって交感神 経の興㟢性が高まり（疼痛を起し）、相生線の逆の方 向一つめを指圧すると、指圧部位の交感神経の興鹪性 が高まり、一つ左まわりには交感神経の興㚚性が抑制 されるので、先の指圧痛が軽減されると解し得る。以 上は指圧直後の值で10分以後ではその反対になってく る場合が多い。

\section{第 4 項 考按及ひ結語}

五行説は易学の理論を人体に無理にあてはめたもの であるとなす説があり、又形隹をととのえる為に相当 無理な点がある等之相当警告的な意見が多い。現代科 学に関係のある人程この様な考えを持つ人が多い。著 者の実験も東洋古法の理論を証明する為に行ったもの ではなく、唯古典に比较検討し、之にあてはまるかの 如き結果を偶然の一致とも考えられる程予想外の照合 的結果が得られるに警くのみである。第一実験より、 第三実験の結果上りみる時、古典五行説、相生、相起 線という哲理は荒唐無稭の空説として排し去り難きを 觉えしめるすのがある。古人が経験より大局的に一つ の大きい傾向を把握して、かかる帰納的命題を普遍妥 当律として通用せしめんとしたものが易学の理論と相 似的な取扱が可能なので之を取り入れ、其の後易学の 理諭を土台にして或種の組立てを行っていった為に、 吏際にはずれた理論も生じた処あると解すべきである まいか。

又一方では、経験を土台にして得た或程度の帰納的 命題の進展に五行説の理論だけでは割り切れないもの を生じたので75難の治療変則という様なすのが出来た のではなかろうか。このととは古人が五行にとらわれ ないで経験を主にして例外的変則を作ったものと看做 すへく、五行説原则が経験に於ても合理的の処があっ たということにもなろう。又、古典では虚するには母 を補しという言葉がある。虚とは病邪に対する身体の 
力、生命力、抵抗力の弱いもので、これを良導絡的見 地加云うと測定值の $\mu^{\mathrm{A}} \mathrm{A}$ 量が多いあのは実 $\mu \mathrm{A}$ 量の 少いむのを虚と考元得よう。 $\mathrm{F}_{5} 11$ が $\mu \mathrm{A}$ 量が少い時 はその母というのは相生関係の逆一つめをいうので $\mathrm{F}$ 46 にあたるを補し、補しとは良導絡では $\mu \mathrm{A}$ 量の增加 する様な刺激を与えようというととである。すると、 その子、 $\mathrm{F}_{5} 11$ は刺激直後では $\mu \mathrm{A}$ 量が減少するが、10 数分後では $\mu \mathrm{A}$ 量が増加すると考えられる。乙の様な 関係が第三実験の結果に現われているととは興味ある 現象と云ってよかろう。しかしての程度の実験から五 行説が正しいといったようなととはいえない、唯実に 弱い傾向であってもこうした結果が偶然にしろ現われ たということにも興味をったにすぎない。

\section{第10章＼cjkstart五伝導方向と興稫線、抑制線に 関する研究}

\section{第 1 項 緒 言}

五行説が必ずしも荒唐無嵇な架空説でなく、笹川の 喝破せる如く哲理を包蔵すべきてとが推せられる様な 実験事実が得られたので、むう少し、掘り下げててれ を研究する興味之必要とが生じて来た。疾患に於ける 代表測定点の $\mu \mathrm{A}$ 量の变化から、どの良導絡の興鹪性 が高まっている時どの良導絡の興虽性が低下している てとが多いとか、逆にどの良導絡の興鹪性が低下して いる時に、どの良導絡の興鹪性が高まっているてとが 多いとかいう様なととについて検討を試みようとし た。そして五グループのうち、或る良導絡の興啗性が 低下している時、良導絡の興鹤性が高まって最す多く 現われるグループへの方向を興鹪線。或る良導絡の興 㟢性が高まっている時、他の良導絡の興窟性が低下し て最も多く現われるグループへの方向を抑制線と名づ けた。との様な名称は刺激生理学上、正確な言葉では ないが、概念の把握がしやすいから、あえて、との様 な言葉を使用するとととした。

入沢(53)はウレタン麻酔家鬼の膀胱を $2 \%$ 食湓水で膨 大し、小腸の運動、及び緊張に反ぼす影響を観察し、
次の結論を述へててい。

(1) 䧛胱膨大による小腸運動の抑制及び腸壁筋緊張の 低下は、䧛胱内壁に存在する求心性神経の圧受容器 が圧迫により機械的に刺湤されるために起る一種の 圧反射である。

（2）此の反射弓は膀胱から下腹神経を経て胸跹第 13 後 根、及び腰髅第 1 後根を介して脊骾に入り、上行し て延髄に興奮が達する様な経路であって、遠心路は 迷走神経之内臟神 経とである。

（3）迷走神経中には腸運動に対して促進及び抑制の 2 線維が含まれ、内臓神経中には促進神経の存在は証 明し得なかった、とのべている。てれは膀胱から、 小腸へは古典でいう相赾線にあたるととと照合して 興味がある。

銭場、内藤 (54)はウレタン麻酔犬に於て、胃及び小 腸の運動を balloon method で描記させ、小腸片に 5 \%食塩水を滴下した。小腸の運動及び腸壁筋緊張が著 しく増大する時は、反射的に胃の緊張は低下し、或は 其の運動は一過性に全く消失する。この反射は両侧迷 走神経及び大小内臟神経の切断、腰部交感神経節状索 の摘出によって消失しない、しかし腹腔及び上腸間膜 神経節の摘出或は之れら神経節へのニコチン塗布及び 腸間膜神経の切断又はコカインによる遮断等によって 消失するから、小腸 $\rightarrow$ 胃反射は之ら神経節を反射中枢 とするあのであるとのべている。てれは古典によれば 小腸 $\rightarrow$ 胃で相生関係にあるととと照合し得よう。

以上の反射は脳に於ける中枢を介しない現象で、腹 腔及び上腸間膜神経節に反射中枢があり、この様な反 応が現われたと考えられている。之は古典の考えに一 致しない。それは末梢に於ける単純なる反射による影 響であるからと考えている。五行的な複雑なる相生、 相起関係が人体に於て哲理を持して厳存するならば、 それは自律神経及びその中枢乃至それに関係深い中枢 飞如斯反射機転を求め得られるのではないかと考えら れる。斯る考が妥当性を有するか否加就いて何等加 の手掛りが得られ好と考元次の如き実験を試みた。 